\title{
Rheumatology education in US pediatric residency programs: results of a comprehensive program director survey
}

\author{
Megan L Curran ${ }^{1 *}$, Yasmin Husain ${ }^{2}$ \\ From 2011 Pediatric Rheumatology Symposium sponsored by the American College of Rheumatology \\ Miami, FL, USA. 2-5 June 2011
}

\section{Purpose}

Rheumatology is one of the smallest subspecialties in the field of pediatrics. Due to the deficiency of pediatric rheumatologists in the U.S., there is a shortage of educators. Previous research showed that $40 \%$ of pediatric residency programs have no pediatric rheumatologist on faculty. Although previous studies described the availability of rheumatology training in pediatric residency programs, little is known about the educational content or methods. To develop useful educational curricula for residency program use, rheumatology educators need to understand how pediatric residents are currently taught about rheumatology as well as residency programs' perceived educational needs and barriers.

\section{Methods}

In the summer of 2010, all pediatric residency program directors in the U.S. and U.S. territories were sent email and paper surveys. Contact information was collected using databases from the American College of Graduate Medical Education and the American Medical Association. Email surveys were sent twice via Survey Monkey three weeks apart. One paper survey and a reminder postcard were sent via U.S. mail.

\section{Results}

115 of 197 (58.4\%) program directors have responded to date. $68 \%$ of programs were university based, $26 \%$ community based and 5\% were described as "other." $65 \%$ said that their institution employed pediatric rheumatologists, $34 \%$ had no rheumatologist and $1 \%$ were unsure. $69 \%$ of responding programs lack a required rheumatology

${ }^{1}$ Children's Memorial Hospital, Chicago, IL, USA

Full list of author information is available at the end of the article rotation. 29\% have required rotations supervised by rheumatologists: $12 \%$ include both inpatient and outpatient experience, $8 \%$ only inpatient and $9 \%$ only outpatient. $1 \%$ of programs have a required rotation not supervised by a rheumatologist. Educational goals and objectives are not provided to residents in $26 \%$ of programs. Of 91 responding programs, rheumatology material is taught by general pediatricians in $73 \%$, orthopedists in $56 \%$, faculty rheumatologists in $53 \%$, visiting pediatric rheumatologists in $23 \%$, chief residents in $23 \%$ and senior residents in $15 \%$. Rheumatology is taught via inpatient rounds in 78/87 programs (90\%), lectures with slides in 83/88 (94\%), informal lecture in 54/77 (70\%), demonstration of musculoskeletal exam in $78 / 87$ (90\%), video in 6/64 (9\%), case based discussion in $62 / 76(82 \%)$, online coursework in 4/63 (6\%), and by board question review in 77/83 (93\%). More program directors indicated that residents like live musculoskeletal exam demonstration (95\%) compared to video demonstration (59\%). Interactive case based lectures and Jeopardy games were perceived to be well-liked at $98 \%$ and $90 \%$. Many programs would spend more time teaching rheumatology if a curriculum was provided. Teaching by general pediatricians, chief residents and senior residents would increase. $55 \%$ agreed that having insufficient faculty is a barrier to rheumatology education. $42 \%$ agreed that poor access to teaching resources is a barrier.

\section{Conclusion}

Our survey results provide a detailed picture of how rheumatology is taught in pediatric residency and how teaching can be improved. This information is a foundation for the development of teaching materials that will be targeted for residency programs with little rheumatologist contact.
C Biomed Central

() 2012 Curran and Husain; licensee BioMed Central Ltd. This is an Open Access article distributed under the terms of the Creative Commons Attribution License (http://creativecommons.org/licenses/by/2.0), which permits unrestricted use, distribution, and reproduction in any medium, provided the original work is properly cited. 


\section{Disclosure}

Megan L. Curran: None; Yasmin Husain: None.

\section{Author details}

'Children's Memorial Hospital, Chicago, IL, USA. ${ }^{2}$ University of Pennsylvania

Medical School, Philadelphia, PA, USA.

Published: 13 July 2012

\section{doi:10.1186/1546-0096-10-S1-A7}

Cite this article as: Curran and Husain: Rheumatology education in US pediatric residency programs: results of a comprehensive program director survey. Pediatric Rheumatology 2012 10(Suppl 1):A7.

Submit your next manuscript to BioMed Central and take full advantage of:

- Convenient online submission

- Thorough peer review

- No space constraints or color figure charges

- Immediate publication on acceptance

- Inclusion in PubMed, CAS, Scopus and Google Scholar

- Research which is freely available for redistribution

Submit your manuscript at www.biomedcentral.com/submit
Ciomed Central 